\title{
Assessment of the recreational potential of the forest territory of the Sverdlovsk region
}

\author{
Olga Mezenina ${ }^{1, *}$, Anna Mikhailova ${ }^{1}$, Margarita Kuzmina ${ }^{1}$, Peter Kokovin ${ }^{1}$ \\ ${ }^{1}$ Ural state forest engineering university, Siberian tract, 37, 620100, Ekaterinburg, Russia
}

\begin{abstract}
The purpose of this study is to present our vision of assessing the recreational potential of the territory (RPT) for its effective management. We suggest using this territory assessment method, which consists of two main stages: assessment of the recreational component of the natural environment and assessment of the necessary amount of investment to use the recreational biodiversity of the territories. The article analyzes the approaches and presents the results of a comprehensive assessment of the recreational potential of the forest lands of the Sverdlovsk region. Created a map ranking the Sverdlovsk region according to the results of research with application for developing a comprehensive assessment of RPT on the methods, developed on the basis of the theory of "games with nature": the method of structured comparison of RPT on the Hurwitz criterion, aspiring to the maximum and to identify the factors dominating the impact from the application of the Wald criterion. Based on the conducted research on the analysis of the influence of forests on the formation of recreational characteristics, the authors obtained weighted average generalized coefficients of recreational attractiveness of forests of different types in the forest management areas of the Sverdlovsk region and identified 10 forestcadastre areas in the Sverdlovsk region. This paper also presents a developed and tested method for a comprehensive assessment of the recreational potential of forest lands in the territory of the Sverdlovsk region in order to attract investment. Preliminary investment volumes for the development of the Sverdlovsk region's RPT (based on the cost of forest biodiversity) are presented. We consider the proposed territory ranking to be a necessary indicator for effective management of the subject's territories.
\end{abstract}

\section{Introduction}

To date, Russian and foreign science has accumulated considerable experience in assessing the recreational potential of the territory and spatial planning of recreational facilities [1-5].

Most methods of assessing the recreational potential of the territory are focused on the score of territorial complexes, although there are attempts to assess the economic recreational potential [4].

\footnotetext{
* Corresponding author: mob.61@mail.ru
} 
Professor V.S. Preobrazhensky defined the territorial recreational system as a social economic and geographical system consisting of interconnected subsystems: natural and cultural complexes, engineering structures, service personnel and visitors, characterized by functional and territorial integrity.

The main elements of the recreational potential of the territory (RPT) are its recreational resources (plant, including forest), natural (soil, terrain, climate); elements of the social complex (number, social characteristics of the population, including health status, indicating the main specializations of health improvement, living standards; characteristics of environmental pollution (atmosphere and hydrosphere), the volume of waste stored on the earth's surface; an infrastructure complex that reflects the characteristics of the development of the territory's forest resources, including investment in the regions $[1,2,4,5,6]$.

Assessment of the recreational potential of the territory is one of the most important criteria for rational spatial organization of territorial recreational systems. Thanks to the assessment of the recreational potential of a particular territory, it becomes possible to determine its uniqueness and attractiveness as a whole, as well as the value of its individual components, and possible ways of rational use and development of this territory are determined.

Based on the analysis of research by many scientists in general, the entire procedure for a comprehensive assessment of the recreational potential of the territory can be presented in the following form $[1,2,4,5,6]$ :

1) analytical review of the components of RPT - preparation of matrices describing factors;

2) development of a scheme for linking RPT complexes;

3) determination of evaluation factors and their classification by purpose;

4) identification of principles for developing a methodological approach;

5) formalization of indicators of the state of evaluation factors in order to bring them to a single measurement system;

6) determining the criteria for evaluating the RPT;

7) development of justification for the choice of directions for the development of RPT.

\section{Methods}

Methodological approach of the comprehensive multifactorial assessment of RPT is based on the exclusion of costs related to the organization and functioning of the process of technological processes of development of recreational resources, and consists of two main stages: evaluation of the recreation component of the natural environment and assessment of the required amount of investment for the use of recreational and biodiversity areas.

The first stage of evaluation. The choice of factors for assessing the RPT of forests as a conditioned natural formation is carried out taking into account the specialization and intensity of the recreational impact of the natural environment. At the same time, methods developed on the basis of the theory of "games with nature" are used as the basis for developing a comprehensive assessment of RPT. Two types of evaluation criteria are calculated: a comprehensive comparison of the RPT according to the Hurwitz criterion, which tends to the maximum, and the identification of factors of dominant influence using the Wald criterion $[9,10,11]$.

The selection of objects for development is carried out according to the Hurwitz criterion and the indicator of the intensity of the recreational impact of the natural environment (1): 


$$
Q_{i j}^{V}=\frac{\sum_{j=1}^{p} A_{i j} \cdot \gamma_{i j}}{M_{i j}},
$$

where: $n$ - the amount of RPT, Q- intensity of the impact of the recovery potential i kind j RTP ( in weights, volumetric or conditionally equivalent units), per user, taking into account the health specialization of the recreational environment; $\mathrm{A}_{\mathrm{ij}}$ - recreational resource reserves $\mathrm{i}$ kind $\mathrm{j}$ RPT ( $\mathrm{in}$ weights, volumetric or conditionally equivalent units); $\mathrm{Y}_{\mathrm{ij}}{ }^{-}$ indicator of the normative value of positive activity $\mathrm{i}$ kind $\mathrm{j}$ RPT (in share units, in \%); $\mathrm{M}_{\mathrm{ij}}-$ the area of the land (depending on the objectives of the study) distribution of recreational resources (ha).

The main provisions of the assessment at this stage are to create a game situation in which the role of the main player is played by a part of the population as a recreational user, acting independently or through an active intermediary providing recreational services. The interest's recreant is in receipt of the maximum possible health effect at the lowest cost, and in the interest of the intermediary is to obtain the maximum economic effect at the ongoing phytorecreatic potential of the territory.

The total intensity of the recreational potential of the territory is the sum of the intensity of impacts of all types (all ingredients of the phytorecreatic potential of the territories.

Indicators are grouped according to the accepted classification of recreational potential components. There are groups of indicators that reflect the state of natural conditions (climate, terrain), recreational resources (plant, forest, biological, water), the environmental state of the RPT (the level of environmental pollution) and a group of indicators that characterize the level of economic development (the state of transport infrastructure, the development of hunting or agriculture, etc.).

The difficulty of a comprehensive assessment of the RPT on the intensity of the impact of recreational potential is associated with the formalization of the characteristics given in the accepted units of measurement to a single type of designation.

The conditional equivalent unit (UE) of measurement (2) is proposed as such a unit):

$$
\mathrm{P}_{\mathrm{ij}}=\mathrm{R}_{\mathrm{ij}} /\left|\mathrm{R}_{\mathrm{ij} \text { bas }}\right|, \quad \text { subject to } \quad \mathrm{R}_{\mathrm{ij} \text { bas }} \neq 0,
$$

where: $P_{i j}$ - conditionally equivalent value $i$ of a characteristic indicator $j$ RPT. $R_{i j b a s-}$ basic value $i$ of the characteristic indicator (in generally accepted units of dimension). The minimum or maximum value of the $i$ indicator is proposed by the base $j$ RPT; $R_{i j}$ - value $i$ of the indicator $\mathrm{j}$ RPT (in common unit).

As it was said before this problem is solved by the method of modeling the situation by type "Games with nature" []. Justified for the choice of RPT at this stage is the possible healing effect of the recreant from staying under the influence of the phytorecreatic potential:

$$
\mathrm{A}=\left|\mathrm{a}_{\mathrm{ij}}\right|,
$$

where: $A_{i j}$ the user effect when implemented i recreational service options for $\mathrm{j}$ RPT condition $(i=1, \ldots, m, \ldots, n)$.

The best option for the user is the one that provides the minimum value of the missed opportunity.

The choice of an option is made using the Hurwitz pessimism-optimism criterion, which has the advantage of taking into account both optimistic and pessimistic options for setting the weights of each of them depending on the actual state of the RPT. The optimality index $\mathrm{H}$ is calculated using the formula 3 :

$$
H(\lambda)=\max _{1 \leq i \leq m}\left[(1-\lambda) \min _{1 \leq j \leq n} a_{i j}+\lambda \max _{1 \leq j \leq n} a_{i j}\right]=(1-\lambda) \min _{1 \leq i \leq n} a_{i o j}+\lambda \max _{1 \leq j \leq n} a_{i o j}=H_{i o}(\lambda),
$$


where: $H(\lambda)=H_{\text {io }}(\lambda)$ - a measure of optimality. At the same time, as the 1 value decreases, optimism decreases.

The factors that have the greatest impact on the results of the assessment using the Hurwitz criterion are determined by the Wald criterion.

In conditions of uncertainty and risk, the consumer's choice may not correspond to the necessary recreational specialization. In this case, the problem is solved using a matrix of risks or missed opportunities: $R=\left\|r_{\mathrm{i} j}\right\|_{m, n}$

At the same time risk $r_{i j}$ of the user by variant $\mathrm{Ai}$ and the RPT condition $\mathrm{P}_{\mathrm{j}}$ we will call the difference between the effect that the user will get if he knows about the most favorable territory of the RPT $\mathrm{P}_{\mathrm{j}}$ and effect in the absence of exhaustive information.

$$
r_{i j}-b_{i j}-a_{i j}, b_{i j}=\max a_{i j} \text { (given } j \text { ). }
$$

At the second stage, the considered technologies for the development of recreational resources are evaluated and compared according to the value of cost criteria: the minimum of total costs and the maximum of discounted profit, i.e. this methodological approach provides a multi-factor assessment of the recreational component of the natural environment as an objectively determined natural formation and consideration (evaluation and comparison) of all possible technologies for the development of the natural environment.

The second stage of the assessment allows determining the initial amount of investment required for recreational use of biodiversity of phytomass of plant resources, regardless of the technology of their development [5,6].

Proposed the methodology for determining the required investment volume includes several settlement operations.

The first group of calculations includes the cost of biodiversity, which includes the following components:

a) cost of wood stock

b) the cost of gum:

c) the cost of secondary forest resources

d) the average value of the indirect uses of the forest:

e) the average cost of using forests for hunting purposes.

The second group of indicators can be obtained when assessing the environmental functions of forest ecosystems, including:

a) functions of the forest in maintaining the air composition of the atmosphere.

b) the cost of water protection and water regulation functions of the forest.

c) the cost of the climate-forming function of the forest.

d) the cost of the soil-forming function of the forest.

e) the cost of the forest's water treatment function.

e) the cost of the forest's soil protection function.

g) the cost of the air cleaning function of the forest.

h) the cost of the protective function of the forest.

I) the cost of the resource-saving function of the forest.

The third group of assessment consists of indicators of social functions of forests, including:

a) assessment of the recreational function of the forest. When assessing the recreational function of the forest landscape, the degree of stability of the forest ecosystem to the effects of recreational loads is considered. Recreational load - an integrated indicator of recreational impact, determined by the number of vacationers per unit area, the time of their 
stay at the recreation facility and the type of recreation. Recreational loads are measured by the one - time number of vacationers per unit area on average for the accounting period.

b) the cost of the health function of the forest.

The economic assessment of the health function of the forest is related to the assessment of the recreational role of the forest and is based on the cost of "free time".

c) the cost of the educational function of the forest.

d) the cost of the aesthetic function of the forest.

An integrated indicator of recreational impact is recreational loads, which are determined by the number of vacationers per unit area, the time of their stay at the recreation facility, and the type of recreation. When measuring recreational loads, usually set a single number of vacationers per unit area ( $1 \mathrm{ha})$ on average for the accounting period (a year is 8760 hours), or the total time of rest per unit area for the accounting period $[5,6]$.

In practice, the first method is more often used.

\section{Results and Discussion}

The Sverdlovsk region covers the northern and middle part of the Ural Mountains, as well as part of the West Siberian plain. Most of the territories - 82\% - are occupied by forests, usually coniferous and mixed (Fig. 1) Typical forest types for the region are birch, pine, spruce, cedar, and aspen. It is interesting that even in areas of large cities, in particular Yekaterinburg, a strip of forest occupies a fairly large space - about $66 \%$.

For the Sverdlovsk oblast forests work on the determination of allowable recreational loads was conducted at the Institute of forest, Ural branch, Russian Academy of Sciences, which found that among the main tree species are most sensitive to recreational loads spruce, followed by pine and hardwoods. Thus, natural zones, subzones, terrain, forest types, and the main forest-forming breed were factors that caused the differentiation of permissible recreational loads for forest areas depending on their degree of fitness for recreation.

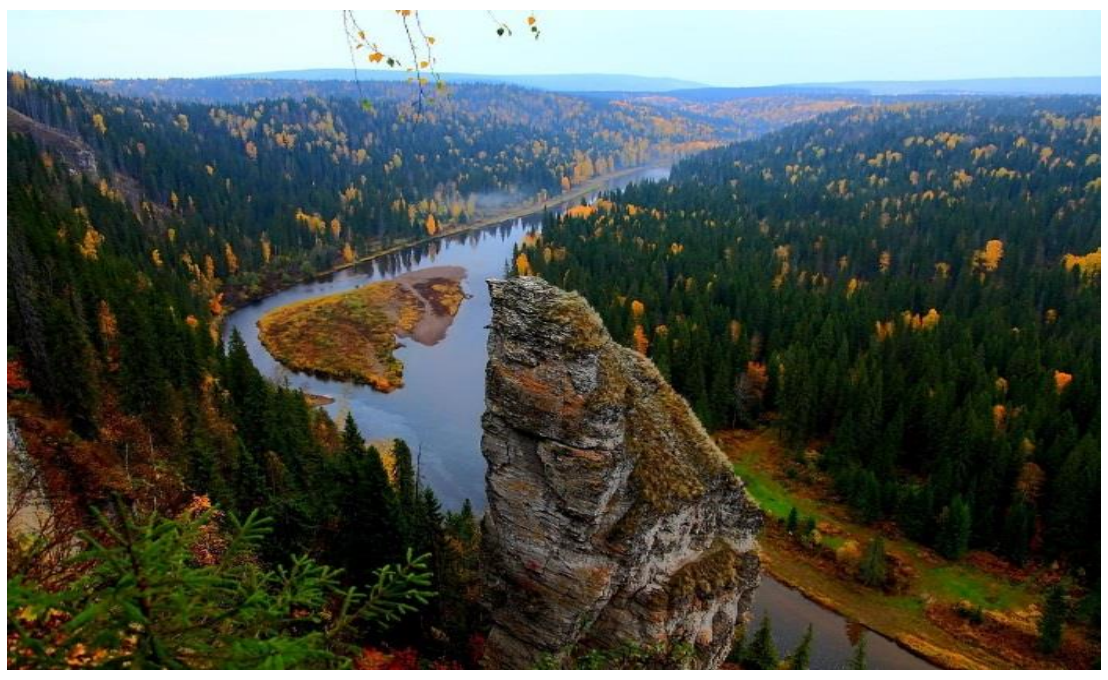

Fig. 1. Natural landscapes of the Sverdlovsk region.

A significant amount of information has been accumulated on the issues of forest resistance to recreational loads in different conditions and regions. On the basis of these data, specialists of the all-Union research Institute of forest mechanization (VNIILM) compiled enlarged "Norms of permissible recreational loads" for flat forests of the taiga - 
forest zone of the European part of the USSR, forest and forest-steppe zones of the Ukrainian SSR, for mountain forests of the North Caucasus, Crimea and the Carpathians. Long-term research in the taiga-forest zone of the European part of the USSR has established that the most resistant to recreation are plantations of subzones of coniferous and broad-leaved forests. Established for forests in this subzone norms of permissible recreational loads are recommended to reduce as the reduction of natural resources in the subzones of southern taiga 1.3, middle taiga 1.7 and Northern taiga 2.5 times.

The value of recreational loads in assessing the recreational role of forests should be linked to the actual need for people to rest in the forest. According to research by Spa specialists, 0.8 of the population of the European part of the country spends their free time in the forest, where they spend an average of 70 hours a year; Muscovites and St. Petersburg residents spend 113 hours, residents of large cities (with a population of about 1 million people) - 83 hours, cities with a smaller population - 47 hours, and residents of rural areas -18 hours. This data is used to justify the actual need for people to rest in various forest-cadastre districts. The actual attendance of the forest for recreation purposes (as opposed to the maximum allowable recreational loads for biological parameters) depends on the recreational attractiveness of forest areas in their accessibility, taking into account such landscape and taxational features as terrain, soil moisture, and the class of bonitet. Based on the above-mentioned research on the analysis of the influence of forests on the formation of

recreational characteristics, the author obtained weighted average generalized coefficients of recreational attractiveness of forests of different types for forest management regions of the Sverdlovsk region (Table 1.).

Table 1. Generalized coefficients of comparative recreational (aesthetic) attractiveness of forests by forest management regions of the Sverdlovsk region.

\begin{tabular}{|c|c|c|c|c|}
\hline \multirow{2}{*}{ Forestry area } & \multicolumn{4}{|c|}{ Forest species } \\
\cline { 2 - 5 } & Pine & Spruce & Birch & Limes \\
\hline Severouralsky mountain & 1.5 & 0.7 & 1.4 & - \\
\hline Lozvinsko-Pelymsky flat & 1.0 & 0.5 & 1.3 & - \\
\hline $\begin{array}{c}\text { Sosvinsko-Turinsky mountain } \\
\text { plain }\end{array}$ & 0.9 & 0.6 & 1.2 & - \\
\hline $\begin{array}{c}\text { Kachkanarsko-Tavdinsky } \\
\text { mountain }\end{array}$ & 1.5 & 0.7 & 1.3 & - \\
\hline $\begin{array}{c}\text { Serginsko-Chusovskoy } \\
\text { mountain }\end{array}$ & 1.5 & 0.9 & 1.4 & 1.5 \\
\hline $\begin{array}{c}\text { Tagilsko-Sverdlovsky } \\
\text { Zauralsky piedmont }\end{array}$ & 1.5 & 0.6 & 1.3 & - \\
\hline Pre-steppe pine-birch flat & 1.6 & 0.4 & 1.1 & - \\
\hline
\end{tabular}

Based on the results of a comprehensive assessment using the Hurwitz and Wald criteria, it was possible to identify 10 forest-cadastre areas in the Sverdlovsk region and create a map-scheme of areas ranked by attractiveness, which is considered necessary for the development of territories in other countries [12] (Fig. 2), the characteristics of which allow us to draw the following conclusions: 

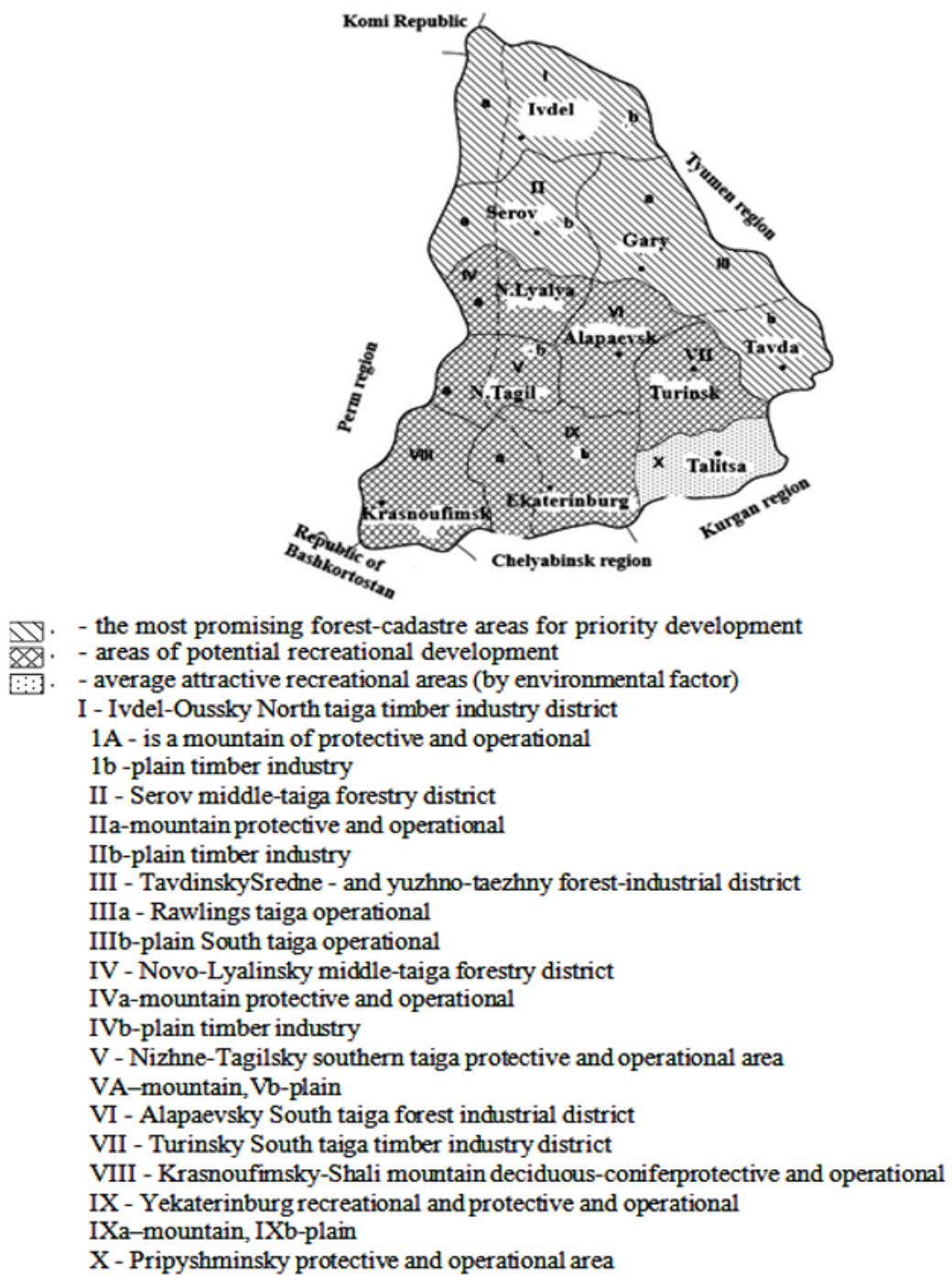

Fig. 2. Scheme of forest-cadastral zoning of the Sverdlovsk region taking into account the investment attractiveness in recreational activities.

a) as a priority for the development of the recreational potential are highlighted in the following forest-cadastre areas of Sverdlovsk region are: VI - Turinsky (South-taiga forestry district); VII - Alapayevsky (southern taiga forestry district); X - Pripyshminsky (protective and operational district).

The factors that have determined the prestige of these areas are: the recreational capacity of the territories, the intensity of the recreational impact, the relatively low level of man-made environmental pollution in comparison with other forest-cadastre areas, favorable climatic conditions, and, as a relatively negative condition, the lack of development of transport infrastructure.

b) development of the recreational potential of the IX forest-cadastre district of the region - Yekaterinburg (recreational and protective - operational) - depends on the 
specialization of economic activity and the need for a sharp reduction in the level of technogenic pollution of the environment;

c) the state of the natural environment, environmental pollution and level of economic development, investment in the development and organization of recreational services is not recommended forest-cadastre in the following districts: IV - Novo-Lyalinsky (middletaiga forestry district ); V-Nizhny Tagilsky (southern taiga protective operational area); VI Alapayevsky (South-taiga forestry district); VII - Turinsky (South-taiga forestry district); VIII - Krasnoufimsky-Shali (mountain deciduous-conifer).

The authors analyzed the research of some scientists on possible investment in recreational areas [7,8] and presented a developed and tested methodology for a comprehensive assessment of the recreational potential of the forest potential of the territory of the Sverdlovsk region (municipal, cadastral and other areas, forestry, forest parks, etc.) in order to attract investment. This technique includes the following steps:

1. Conducting preparatory work to collect the necessary information, including:

a) the reserves of phytomass of coniferous and deciduous breeds, phyto-diversity these types of rocks, the intensity of recreation impact in accordance with the natural structure of wood;

b) characteristics of natural and spatial conditions of forest-cadastral areas (average annual air temperatures, precipitation, types of terrain, types of soils, etc.);

c) characteristics of pollution of territories (volumes of technogenic emissions into the atmosphere, into the hydrosphere, total volumes of industrial waste stored on the surface, etc.);

d) indicators of potential opportunities for providing recreational services to the population (recreant and intermediaries);

e) environmental indicators of the investment and industrial complex (IPC) (the composition of specialized industrial enterprises in the region, the state of the investment climate of these enterprises, investment flows aimed at solving environmental problems, the availability of innovative programs, etc.).

2. Ranking of forest-cadastre areas and other territories based on a factor assessment of their phyto-recreational potential of the territory (RPT).

At this stage, two types of evaluation criteria are calculated for each factor: a) a comprehensive comparison of the FRPT taking into account the considered factors (according to the Hurwitz criterion) and b) identification of dominant influence factors (using the Wald criterion) $[9,10,11]$.

To do this, we select the maximum and minimum values from all absolute values of indicators of the ecological state of forest-cadastre areas, identify the results of formalization of absolute values of pollution characteristics using mathematical data processing, and rank forest-cadastre areas by the degree of pollution.

In the article, we can present a summary matrix for the characteristics of groups of factors obtained as a result of the assessment using the Hurwitz and Wald criteria for the results of ranking the development of RPT, which is reflected in table 2.

Table 2. Results of RPT ranking by rating factor groups.

\begin{tabular}{|c|c|c|c|c|c|c|c|c|c|}
\hline \multirow{2}{*}{$\begin{array}{c}\text { Fore } \\
\text { st- } \\
\text { cada } \\
\text { stre } \\
\text { area } \\
\text { s } \\
\end{array}$} & $\begin{array}{c}\text { Hurwit } \\
\text { z }\end{array}$ & \multirow{2}{*}{$\begin{array}{l}\text { Natural } \\
\text { resources }\end{array}$} & \multirow{2}{*}{$\begin{array}{c}\text { Natural } \\
\text { condition } \\
\mathrm{s}\end{array}$} & \multirow{2}{*}{$\begin{array}{l}\text { Biodivers } \\
\text { ity }\end{array}$} & \multirow{2}{*}{$\begin{array}{l}\text { Ecologi } \\
\text { cal } \\
\text { factors }\end{array}$} & \multirow{2}{*}{$\begin{array}{l}\text { Justificatio } \\
\text { n of } \\
\text { prospects } \\
\text { for } \\
\text { recreationa } \\
1 \text { resources }\end{array}$} & \multirow{2}{*}{$\begin{array}{l}\text { Distric } \\
\text { ts } \\
\text { invest } \\
\text { ment } \\
\text { potenti } \\
\text { al }\end{array}$} & \multirow{2}{*}{$\Sigma$} & \multirow{2}{*}{$\begin{array}{c}\text { Ran } \\
k\end{array}$} \\
\hline & Wald & & & & & & & & \\
\hline \multirow{2}{*}{ I } & A & $2-1$ & $2-3$ & $1-1$ & 6-7 & $2-2$ & $6-6$ & 19.5 & 10 \\
\hline & B & 8 & 1 & 2 & 7 & 1 & 7 & 26 & 7 \\
\hline \multirow{2}{*}{ II } & A & $4-4$ & $3-2$ & $4-4$ & $9-9$ & $4-4$ & $5-5$ & 28.5 & 7 \\
\hline & B & 7 & 2 & 4 & 4 & 3 & 3 & 23 & 8 \\
\hline
\end{tabular}




\begin{tabular}{|c|c|c|c|c|c|c|c|c|c|}
\hline \multirow{2}{*}{ III } & $\mathrm{A}$ & $3-2$ & $6-6$ & $3-3$ & $2-2$ & $3-3$ & $10-10$ & 26.5 & 8 \\
\cline { 2 - 10 } & $\mathrm{B}$ & 6 & 5 & 3 & 6 & 2 & 9 & 31 & 5 \\
\hline \multirow{2}{*}{ IV } & $\mathrm{A}$ & $7-7$ & $4-4$ & $7-7$ & $8-8$ & $10-10$ & $7-9$ & 44 & 2 \\
\cline { 2 - 11 } & $\mathrm{B}$ & 3 & 3 & 7 & 3 & 9 & 4 & 29 & 6 \\
\hline \multirow{2}{*}{$\mathrm{V}$} & $\mathrm{A}$ & $5-6$ & $5-5$ & $5-5$ & $10-10$ & $7-7$ & $2-2$ & 29.5 & 6 \\
\cline { 2 - 11 } & $\mathrm{B}$ & 2 & 4 & 5 & 1 & 6 & 2 & 20 & 9 \\
\hline \multirow{2}{*}{$\mathrm{VI}$} & $\mathrm{A}$ & $9-9$ & $7-7$ & $9-9$ & $4-5$ & $8-8$ & $4-3$ & 41 & 3 \\
\cline { 2 - 11 } & $\mathrm{B}$ & 9 & 7 & 9 & 8 & 7 & 6 & 46 & 2 \\
\hline \multirow{2}{*}{$\mathrm{VII}$} & $\mathrm{A}$ & $8-8$ & $9-9$ & $8-8$ & $5-4$ & $9-9$ & $9-7$ & 46.5 & 1 \\
\cline { 2 - 11 } & $\mathrm{B}$ & 4 & 6 & 8 & 5 & 8 & 8 & 39 & 3 \\
\hline \multirow{2}{*}{$\mathrm{VIII}$} & $\mathrm{A}$ & $6-5$ & $8-8$ & $6-6$ & $1-1$ & $6-6$ & $8-8$ & 34.5 & 5 \\
\cline { 2 - 11 } & $\mathrm{B}$ & 5 & 5 & 6 & 8 & 5 & 5 & 34 & 4 \\
\hline \multirow{2}{*}{ IX } & $\mathrm{A}$ & $1-3$ & $1-1$ & $2-2$ & $7-6$ & $5-5$ & $1-1$ & 21.5 & 9 \\
\cline { 2 - 11 } & $\mathrm{B}$ & 1 & 4 & 1 & 2 & 4 & 1 & 13 & 10 \\
\hline \multirow{2}{*}{$\mathrm{X}$} & $\mathrm{A}$ & $10-10$ & $10-10$ & $10-10$ & $3-3$ & $1-1$ & $3-4$ & 37.5 & 4 \\
\cline { 2 - 10 } & $\mathrm{B}$ & 9 & 8 & 10 & 8 & 9 & 3 & 49 & 1 \\
\hline
\end{tabular}

Thus, the highest priority for the development and implementation of investment and innovation in the Sverdlovsk region is Turinsky, Alapayevsky and Pripyshminsky forestcadastre areas, the least efficient Yekaterinburg, Ivdel-Oussky and Nizhny Tagilsky forestcadastre areas.

3. Conducting a cost-based ecological and economic assessment of the recreational potential of the region's forest lands in this example (in the context of forest-cadastre areas).

This estimate consists of the sum of the costs of bioresources, the cost of environmentforming functions, the cost of social functions of forest complex lands, the calculation method of which is presented in detail in the studies of Mezenina O. B. [5,6].

As a result of the value of ecological and economic assessment of forest resource potential forest-cadastre areas of Sverdlovsk region (on the example of the study of the spaces of the "wet forest" in the plains South taiga forest-cadastre area) were obtained indicators, some of which can be used to determine the cadastral value of a typical Ural forest recreational use $[5,6]$.

The final ecological and economic assessment of the recreational potential of the territory is based on the summation of certain types of forest benefits (resources, environmental and social functions) in accordance with the legal status of the assessed forest areas.

The value of the biodiversity of operational forests (second and third groups) is the sum of the values:

- forest resources (wood, oleoresin, secondary or non-wood forest resources, side uses of the forest);

- groups of environment-forming functions that are inherent in the entire forest territory (maintaining the composition of atmospheric air, water protection and water regulation, climate-forming and soil-forming).

The degree of expression of the environment-forming functions of the second and third groups of forests varies depending on the specific environmental conditions of the territory.

The assessment of forest biodiversity of the first group is made in accordance with the number and types of environmental and social functions.

In General, the cost of forest biodiversity in a particular category of protection, according to the above method of calculating all functions of a forest area, is equal to the sum of the values of forest benefits inherent in this category. So, the list of qualifying functions of the forest biodiversity of forest green areas in addition to the cost benefits of the commercial forest is added to the cost of air pollution control, recreational, health functions, and to the value of the forested parts, and forests of green zones is also added and the cost of the educational role. 
So, the cost of 1 ha functions of the recreational area of the Sverdlovsk region analyzed by the authors was 129000 rubles, and the cost of creating 1ha of recreational forests is up to 80000 rubles (taking into account the design of forest management and land management works), i.e. the profitability of this event is obvious, since the costs are paid for in a year.

The proposed scheme of directions for the development of the recreational process in the territory of the Sverdlovsk region is considered as a strategic base for providing recreational services in promising areas for large-scale improvement of the population of the Sverdlovsk region. Provided the average cost of providing recreational services 700/750 RUB /person/day (two times less than the modern average value in the tourism market of Russia - 1200/1500 RUB/person/day) and adopted conditionally the cost of the investor for the development of part salacinol site forest-cadastre area in terms of the value of biodiversity (approximately $70 \%$ of the area), the components of author's estimates from 4 million to 16.9 million/rubles of investments for the organization of recreational services and the development of RPT will pay for itself in 2.5 years (Table 3 ).

If the investor on the results of the multifactorial assessment will define the selected area (square) area is suitable for route activities on it with minimal investment of development (30\% of the total calculated amounts of funding), the payback period will be approximately one year (optimistic project).

Under the condition of incomplete development (2\%) of prospective territories (selected areas by the investor) and incomplete involvement of the region's population in recreational recreation ( $25 \%$ of the region's residents), the investment payback period will be $2.5-3$ years (a real project).

Table 3. Preliminary investment volumes for the development of the Sverdlovsk region RPT (based on the cost of forest biodiversity).

\begin{tabular}{|c|c|c|c|c|c|c|}
\hline $\begin{array}{c}\text { Forest- } \\
\text { cadastr } \\
\text { e area } \\
\text { (indices } \\
\text { ) }\end{array}$ & $\begin{array}{l}\text { Normative } \\
\text { number of } \\
\text { recreational } \\
\text { capacities of } \\
\text { the territory, } \\
\text { person / year }\end{array}$ & $\begin{array}{c}\text { The area is } \\
\text { wooded, } \\
\text { thousand } \\
\text { ha }\end{array}$ & $\begin{array}{c}\text { Volume of } \\
\text { investments } \\
\text { in the area's } \\
\text { biodiversity, } \\
\text { thousand } \\
\text { rubles. }\end{array}$ & $\begin{array}{l}\text { Volume of } \\
\text { investments } \\
\text { for the } \\
\text { development } \\
\text { of the control } \\
\text { section of the } \\
\text { FRPT, } \\
\text { thousand } \\
\text { rubles. }\end{array}$ & $\begin{array}{l}\text { Total annual } \\
\text { revenue } \\
\text { from } \\
\text { recreational } \\
\text { services } \\
\text { FRPT, } \\
\text { thousand } \\
\text { rubles. }\end{array}$ & $\begin{array}{c}\text { Payback } \\
\text { period, } \\
\text { years }\end{array}$ \\
\hline I & 1030000 & 2339 & 24092 & 16864 & 7210 & 2.39 \\
\hline II & 626650 & 1510 & 15553 & 10887 & 4387 & 2.48 \\
\hline III & 898480 & 2042 & 21033 & 14723 & 62960 & 2.34 \\
\hline IV & 376405 & 907 & 9342 & 6540 & 2635 & 2.48 \\
\hline V & 425292 & 1025 & 10557 & 7390 & 2977 & 2.48 \\
\hline VI & 355697 & 857 & 8827 & 6179 & 2490 & 2.48 \\
\hline VII & 350841 & 845 & 8703 & 6092 & 2459 & 2.47 \\
\hline VIII & 472270 & 1138 & 11721 & 8205 & 3306 & 2.48 \\
\hline IX & 541700 & 1305 & 13442 & 9410 & 3792 & 2.48 \\
\hline $\mathrm{X}$ & 239000 & 576 & 5933 & 4153 & 1673 & 2.48 \\
\hline $\begin{array}{c}\text { Total, } \\
\text { includi } \\
\text { ng } \\
\text { on } 1 \\
\text { hectare } \\
\text { (ha) } \\
\end{array}$ & & 12544 & $\begin{array}{c}129203 \\
10.30\end{array}$ & $\begin{array}{c}90443 \\
7.21\end{array}$ & $\begin{array}{c}37225 \\
2.98\end{array}$ & \\
\hline
\end{tabular}

So the value allowed recreational pressure in the forests of this district established for mass every day, leisure, simulation-based categories the surface damage of the soil cover accounting for the "Norms of admissible recreational loads for lowland forests finalizes zone of the European part of the USSR." 
It should be noted that recreational loads are 1.3 times lower in birch and aspen forests, 2.3 times lower in pine forests, and 3.6 times lower in the mountainous part of dark coniferous forests.

For example, on a 10 ha planting herb birch forest type allow more than 12 people for 365 days a year $(8760 \mathrm{~h})$, in a pine forest forb type permissible load is 2.7 times less.

When assessing the recreational role of forests, it is necessary, along with the permissible recreational loads, to take into account the need for people to rest in the forest on this territory.

According to research by Spa specialists, 0.8 of the population of the European part of the country spends their free time in the forest and spends an average of 70 hours a year there, Muscovites and Leningraders-113 hours, residents of large cities (with a population of about 1 million people) - 83 hours, small cities- 47 hours, rural areas-18 hours.

According to professor G.G. Shalmina in the cities of Central Siberia (Novosibirsk, Tomsk, Barnaul), about $70 \%$ of people organize their holidays in the summer, i.e. when the recreational impact on the components of natural objects is greatest: in winter $-6 \%$, in the off - season-24\%.

At the same time, more than $75 \%$ of the population rests on the territory of their residence, including 25-35\% - within their city limits. In General, the demand of the population for recreational services is determined by the income of the population.

To a certain extent, the actual need of people to rest on the territory of forest areas (their attendance) is reflected in the required area of green areas of cities. There are normative data for recommended areas of urban green zones for suburban areas in areas with forest cover of more than $25 \%$.

\section{Conclusions}

The variety of types of nature management in a certain territory depends on its resource availability and conditions for their development, the structure and nature of social needs, the types of existing social needs and the size of the territory. Recently, the problem of assessing the territory for recreational use has been actively investigated by architects, land managers, ecologists, appraisers, geographers, psychologists, experts in the field of tourism and tourism business. The scientist identifies several approaches to this assessment, common to which is a detailed study of the resources and conditions of recreational activities. Basically, the assessment is subject to natural conditions, transport accessibility, availability of recreational infrastructure (buildings, complexes, engineering systems), etc.

The Sverdlovsk region is quite rich in natural and recreational resources. currently, they are used quite well, but mostly on a regional scale. According to the study, we should conclude that the Sverdlovsk region has a great potential for further development and increasing the effective use of the territory for recreational and recreational purposes, including attracting tourists from other regions of Russia and the world, but this requires active actions and investments to improve the environmental situation and develop the tourist infrastructure of the region.

\section{References}

1. F. Riccioli, R. Fratini, E., et al., Socio-Economic Planning Sciences, 100732 (2019) doi: org/10.1016/j.seps.2019.100732

2. Ching Li, Cheng-Ping Wang, et al., Journal of Environmental Management, Issue 11, 91, 2342-2348 (2010) doi.org/10.1016/j.jenvman.2010.06.020 
3. M. Komarova, The typology of methodological approaches to the assessment tourism potential.

4. Scientific herald, 3(5), 16-24 (2015) DOI: 10.17117/nv.2015.03.016

5. Ashley d'Antoni, Christopher Monz, et al., Magazine about outdoor recreation and tourism, 14, 12-21 (2016) doi.org/10.1016/j.jort. 2016.04. 002

6. O. Mezenina, L. Atkina, et al., Moscow economic journal, 3, 72-83 (2019) Doi: 10.24411/2413-046X-2019-13024

7. L. Atkina1, O. Mezenina, et al., FTA IOP Conf. Series: Earth and Environmental Science, 316, 012040 (2019) doi:10.1088/1755-1315/316/1/012040

8. L. Tyrväinen, E. Mäntymaa, et al., Private landowners' preferences for trading forest landscape and recreational values: A choice experiment application in Kuusamo (Finland, Land use policy, 2020) doi.org/10.1016/j.landusepol.2020.104478

9. F. Sgroi, M. Foderà, et al., Ecological Engineering, 90, 399-404 (2016) doi: org/10.1016/j.ecoleng.2016.02.004

10. Goryashko, Cloud of science, 1, №1, 112-154 (2014) doi:10.0000/cyberleninka.ru/article/n/teoriya-igr-ot-analiza-k-sintezu-obzor-rezultatov

11. E. Butsenko, Regional economy, 14, 1, 270-280 (2018) doi: 10.17059/2018-1-21

12. Vorobyev, A. Ganeev, Achievements and applications in discrete mathematics, 19, 2, 93 - 116 (2018) doi.org/10.17654/DM019020093

13. M. A. Meyer, J. Rathmann, Ch. Schultz, Landscape and urban planning, 18, 83-95 (2019) doi.org/10.1016/j.landurbplan.2019.01.007 